\title{
TAKEOVERS, OWNERSHIP STRUCTURES, AND CONTROL PREMIUMS: A COMPARATIVE ANALYSIS ${ }^{1}$
}

\author{
Mariana Pargendler ${ }^{2}$
}

\section{INTRODUCTION}

The takeover debate does not cease to attract scholarly and public attraction. The huge sums involved and the sophisticated techniques of takeover defenses, combined with the inherent conflict of interest present in the use of defensive techniques, have made takeovers one of the most discussed issues in U.S. corporate law.

The subject, however, is extremely controversial. Law-and-economics scholars have praised takeovers as an essential mechanisn, since they offset the agency cost attributed to management control and further the allocation of resources in a more efficient manner. ${ }^{3} \mathrm{On}$ the other hand, takeover detractors claim that they not only harm workers and other constituencies, ${ }^{4}$ but also threaten the development of the U.S. economy. ${ }^{5}$

While the desirability of takeovers remains an unsettled problem, it seems important to highlight that the very feasibility of hostile takeovers is not universal. In Brazil's developing financial market, hostile takeovers are still virtually inexistent. As a result, the focal point in transactions involving the sale of control shifts to the protection of minority shareholders through the legal device known as the "mandatory public offer."

\footnotetext{
Trabalho apresentado para a disciplina de Business Associations, ministrada pelo Professor David S. Sokolow, na Universidade do Texas em Austin. Este trabalho foi por mim realizado como bolsista do programa de intercâmbio FIPSE-CAPES, de janeiro a maio de 2004.

2 Aluna do $10^{\circ}$ semestre da Facuidade de Direito da Universidade Federal do Rio Grande do Sul. Agradeço à Professora Cláudia Lima Marques e ao Programa de Pós-Graduação em Direito da Universidade Federal do Rio Grande do Sul a oportunidade de compartihar a pesquisa realizada nos Estados Unidos por meio destes Cadernos.

${ }^{3}$ Stephen M. Baingrioge, Corporation Law and Economics 694 (2002).

"Andrei Schleifer \& Lawrence H. Summers, Breach of Trust in Hostile Takeovers, in CORPORATE TAKEOVERS: Causes AND CONSEquences 33-56 (A. Auerbarch, ed., 1988).

"Arnoldo Wald, Considerações sobre a aquisiça e alienação do controle societário: a estudo da jurisprudência, 321 Revista Forense 3, 4 (1993). Somewhat surprisingiy, while most American scholars are sympathetic to takeovers, Brazilian academics take a critical view when they investigate takeovers in the U.S. corporate scenario.
} 
In fact, the incidence of hostile takeovers in the United States is far less common than the extensive legal literature on the topic would suggest. In fact, there have been only forty-nine hostile takeover bids for U.S. corporations in the last five years, a trivial figure when compared to the 47,000 announced acquisitions in the same period. ${ }^{6}$ Yet, this data should not imply that takeover regulation is unimportant, especially if we take into account that the low occurrence of takeover is due in large part to the legal admissibility of a wide of variety of takeover defenses by U.S, statutory and case law, ${ }^{7}$ which should have the effect of discouraging further threats. ${ }^{6}$

It is important to note, however, that it is the structural viability of hostile takeoversand not their actual occurrence rate-that determines the emergence of a dense body of takeover law. Indeed, conclusions about the importance of the hostile-takeover phenomenon that focus exclusively on the actual number of targets seem somewhat flawed, because they ignore the desirable general deterrent effect that benefits shareholders in the vast majority of corporations for which a hostile bid is never made. ${ }^{9}$

This paper does not try to offer an exhaustive description of U.S. and Brazilian takeover laws; instead, it aims to demonstrate the reasons for the multitude of differences in takeover regulation between the two countries. The analysis is organized as follows: Part I discusses the essential differences in the ownership structure in Brazil and in the United States. While U.S. corporations seem to comply with the celebrated Berle and Means model, Brazilian companies still have higher levels of ownership concentration. These structural differences shape basic notions of corporate law in both countries.

Part Il examines the impact of the ownership structure on the likelihood of a hostile takeover and its consequences for takeover law. As the chances of a hostile attempt vary according to the degree of dispersion of the corporation's stock, the rules about defensive measures to be implemented by the board of directors receive greater attention where, as in the United States, hostile bids are common enough to become a major concern. Conversely, since

\footnotetext{
${ }^{\circ}$ Mark L. Sirower, Staggering Facts, Wall ST. J., Apr. 13, 2004.

${ }^{7}$ Robert W. Hamilton \& Jonrthan R, Macey, Cases and Materials on Corporations including Partnerships AND LiMited LIABILITY COMPANiES 1226 (2003). As of 2001, a majority of U.S. publicly-held corporations had poison pills. According to Thomson Financial Securities Data, in 2001 the number of companies adopting first-time or amended poison pill measures increased from 235, as compared to 188 for the same period in 2000. The adoption staggered boards- which prevent a hostile acquirer from gaining control of the company in a single election-has also significanty increased. In 1990, only $34 \%$ of corporations going public had such boards, whereas $71 \%$ of their counterparts did. $1 d$. indeed, an empirical study using a data set of hostile bids between 1996 and 2000 showed that efficient staggered boards nearly doubled the average target's odds of remaining independent, from $34 \%$ to $61 \%$, reduced the chances of a bidder completing its bid from $34 \%$ to $14 \%$, and cut the odds that the average target will be forced into selling to a white knight from $32 \%$ to $25 \%$. Lucian Arye Bebchuk et al., The Powerful Antitakeover Force of Staggered Boards: Theory, Evidence, and POlicy, 54 STAN. L. REV. 887, 931 (2002).

- Hamilton \& Macey, supra note 7, at 1239 (2003). Actually, as of 1993 , only $66 \%$ of hostile bids succeed, while as recently as 1999 the success rate reached $80 \%$ of the total attempts. $1 d$. See further discussion on technical and structural barriers for takeovers in Part ll(c).

${ }^{*}$ Coffee Jr. John C., Regulating the Market for Corporate Control: A Critical Assessment of the Tender Offer's Role in Corporate Governance, 84 CoLUM. L. Rev. 1145, 1192 (1984).
} 
hostile bids still represent an unlikely scenario in Brazil, legal rules tend to focus on the protection of minority shareholders where a sale of control, usually agreed outside the public market, occurs.

Part III explores how the different corporate and capital structures affect the importance and the regulation of an issue common to both legal systems: the control premium arising from the sale of control. Although this issue plays a secondary-though still importantrole in the United States, in Brazil sharing of control premium lies at the heart of the regulation of sale of control transactions.

\section{PART I - OWNERSHIP AND CONTROL IN BRAZILIAN AND U.S. CORPORATIONS}

A) Two models of comporate governance: dispersed and concentrated ownership systems Many of the dissimilarities in Brazilian and U.S. corporate law can be explained by the different ownership structures of both countries' publicly held corporations. Since Berle and Means's seminal work, the separation of ownership and control has been described as a distinctive mark of the modern corporations. In theit words, "control divorced from ownership is not ... a familiar concept. It is a characteristic product of the corporate system."

Nevertheless, the separation of ownership and control is not a necessary product of every corporate system. Even though American publicly held corporations on the whole follow such a pattern, Berle and Means's paradigm is not universally accurate. In Brazil, as in other developed and developing countries, ownership is still significantly concentrated. "

A study carried out by an economist at Brazi's National Development Bank (BNDES) analyzed the ownership structure of 278 publicly-held corporations. The research, based on Thomsen and Pedersen's definitions, ${ }^{12}$ revealed that the control structure in Brazil is still distant from Berle and Means's model.

\footnotetext{
${ }^{10}$ Adolf A. Berle, Jr \& Gardiner C. Means, The Modern Corporation and Private Property 69 (1932).

${ }^{11}$ Rafael La Porta et al., Corporate Ownership Around the World, 54 J. FiN. 471, 472 (1999).

12 Tagore V. de Siqueira, Concentration of Owhership in Brazilian Quoted Companies, 10 REvISTA do BNDES (1998), available at http://www.bndes.gov.br/conhecimento/revista.rev1002.pdf (last visited Apr. 11, 2004). The classification follows the model presented in S. THOMPSEN \& T. PEDERSEN, European OWnership Concentration: Causes and Consequences (1997). According to this model, the property is dispersed when the major shareholder has less than $20 \%$ of control, it is dominant when he has between $20 \%$ and $50 \%$ of control, and it is majority when he has more than $50 \%$ of control. A problem to the use of these figures to compare ownership concentration in Brazilian and American companies could arise, however, since Brazilian pubilcly-held companies are not as large as their American analogues. Nevertheless, such an obstacle should not be overestimated. In an attempt to verify the accuracy of Thompsen \& Pedersen studies with regard to the effect of the company's size to the ownership concentration, Tagore $V$. Siqueira observed that, contrary to the cited authors' conclusions, company size had an extremely very weak effect on ownership concentration in Brazil. A possible explanation for such a phenomenon is that Brazilian publicly-held corporations tend to raise funds through bank loans and debt securities (bonds and debentures). rather than through issuance of shares. Therefore, even though some Brazilian companies have considerable size (see Tables 1 and 2), this has not yet triggered higher levels of ownership dispersion.
} 
Table 1: Principal Characteristics of the Sample by Concentration of Ownership ${ }^{13}$

(\% of Total Number of Shares held by Majority Stockholder)

\begin{tabular}{|l|l|l|l|l|}
\hline VARIABLE & \multicolumn{2}{|c|}{ ITEM } & OWNERS HP CONCENTRATION \\
\hline & Dispersed & (Up to 20\%) & $\begin{array}{l}\text { Dominant } \\
\text { (Between 20- } \\
\mathbf{5 0 \%}\end{array}$ & $\begin{array}{l}\text { Majority } \\
\text { (Over 50\%) }\end{array}$ \\
\hline Companies & No. & 59 & 134 & 85 \\
\hline & $\%$ & 21.22 & 48.20 & 30.58 \\
\hline Net Sales (USS) & Average 1994/96 & $747,372,086$ & $616,356,712$ & $602,835,742$ \\
\hline Net Equity (US\$) & Average 1994/96 & $426,809,267$ & $662,983,788$ & $692,786,233$ \\
\hline TotalAssets (US\$) & Average 1994/96 & $1,547,788,386$ & $1,751,848,988$ & $1,357,340,82 !$ \\
\hline $\begin{array}{l}\text { Cost of Sales (CPV) } \\
\text { (US\$) }\end{array}$ & Average 1994/96 & $469,820,845$ & $256,924,340$ & $284,343,090$ \\
\hline Net Pro fit (US\$) & Average 1994/96 & $25,443,552$ & $19,248,744$ & $24,508,146$ \\
\hline
\end{tabular}

Table 2: Principal Characteristics of the Sample by Concentration of Ownership ${ }^{14}$ (\% of Total Number of Voting Shares held by Majority Stockholder)

\begin{tabular}{|c|c|c|c|c|}
\hline \multirow[t]{2}{*}{ VARIAB LE } & \multirow[t]{2}{*}{ TTEM } & \multicolumn{3}{|c|}{ OWNERS HIP CONCENTRATION } \\
\hline & & $\begin{array}{l}\text { Dispersed } \\
\text { (Lp to } 20 \% \text { ) }\end{array}$ & $\begin{array}{l}\text { Dominant } \\
\text { (Between 20- } \\
50 \% \text { ) }\end{array}$ & $\begin{array}{l}\text { Majority } \\
(\text { Over } 50 \%)\end{array}$ \\
\hline Companies & No. & 21 & 69 & 188 \\
\hline & $\%$ & 7.55 & 24.82 & 67.63 \\
\hline Net Sales (US\$) & Average $1994 / 96$ & $1,276,138,418$ & $545,834,974$ & $602,719,994$ \\
\hline Net Equity (USS) & Average 1994/96 & $760,109,432$ & $454,102,664$ & $667,889,515$ \\
\hline Total Assets (US\$) & Average $1994 / 96$ & $2,733,540,359$ & $1,512,183,147$ & $1,489,148,294$ \\
\hline $\begin{array}{l}\text { Cost of Sales (CPV) } \\
\text { (USS) }\end{array}$ & Average $1994 / 96$ & $743,955,105$ & $269,679,262$ & $272,911,707$ \\
\hline Net Profit (US\$) & Average $1994 / 96$ & $43,060,381$ & $2 h, 178,758$ & $20,888,172$ \\
\hline
\end{tabular}

Considering the participation of the main shareholder's stock (i.e, the shareholder with the largest number of shares) in the number of total shares, $59(21.22 \%)$ of the corporations had dispersed ownership, 134 (48.20\%) had dominant ownership, and 85 (30.58\%) had majority 
ownership. ${ }^{15}$ Regarding the proportion of the main shareholder's stock in the number of total voting shares, the degree of concentration of Brazilian's corporation becomes even more apparent: $21(7.55 \%)$ corporations were classified as having dispersed ownership, $69(24.82 \%)$ as having dominant ownership, and $188(67.85 \%)$ as having majority ownership. ${ }^{16}$

The United States as of 1994 presents a completely different picture. The main shareholder holds less than $10 \%$ of the voting stock in $66 \%$ of the U.S. publicly held corporations, between $10 \%$ and $25 \%$ in $17.4 \%$ of the companies, and between $25 \%$ and $50 \%$ in $13 \%$ of them. The main shateholder owns more than $50 \%$ of the voting stock in only $3.6 \%$ of the corporations. ${ }^{17}$

The United States and Brazil, therefore, illustrate two different systems of corporate govennance. The "dispersed ownership system" presents a strong securities market with high transparency standards regarding the disclosure of relevant information about the conporation, and a market for corporate control, which is its "ultimate disciplinary mechanism."18 The "concentrated ownership system," on the contrary, has weak financial markets with low transparency standards, an insignificant market for corporate control, and high private benefits of control ${ }^{19}$, i.e., the benefits the controllers can extract to the detriment of the minority through mechanisms such as above-market salaries, insider trading, unfair self-dealing transactions, and issuance of shares to themselves at dilutive prices. ${ }^{20}$

In a concentrated ownership system, controlling shareholders exercise control over the firm greatly in excess of their cash-flow rights, either by the adoption of a pyramidal control system or by direct management of the corpotation. These firms are not managed by professional and independent managers, but by controlling shareholders. The overlapping of managers and controlling shareholders leads to a problem concerning ownership and control, since management then tends to run the company in a fashion that maximizes the private benefits of control. ${ }^{2:}$

Such a problem is comparable to the agency costs verified in corporations with widely dispersed ownership, in the sense that in both situations the main goal of management is not to

\footnotetext{
${ }^{15} / d$. Although share dispersion in Brazilian corporations has increased slightly over time, the overall changes are not significant. In 1985, a study analyzing 476 Brazilian corporations showed that controllers owned on average $69,8 \%$ of the voting stock. In $18,4 \%$ of the corporations controllers hold between 90 and $100 \%$ of the stock of publicly held corporations. See Nelson Eizirik, O Mito do 'Controle Gerencial' - Alguns Dados Empíricos, 66 Revista de Direito Mercantu 103, 104 (1987).

:6iqueira, supra note Error! Bookmark not defined.

17 Nelson S. Filho, Governança Corporativa: Padrôes Internacionais e Evidências Empiricas no Brasil nos Anos 90, 9 REvISTA Do BNDES, available at http://www.bndes.gov.br/conhecimentol revista/rev906.pdf (last visited Apr. 12, 2004).

18 John C. Coffee, Jr., The Rise of Dispersed Ownership: The Roles of Law and the State in the Separation of Ownership and Control, 111 YALE L. J. 1, 3 (2001).

is $/ d$.

${ }^{20}$ John C. Coffee, Jr., Do Norms Matter? A Cross-Country Evaluation, 149 U. PA. L. REv. 2151, 2157$8(2001)$.

${ }^{21}$ La Porta et al., supra note 11 , at 511.
} 
maximize the profits of the remaining shareholders, but to obtain benefits for themselves to the detriment of the shareholders. The existence of a market for corporate control, however, helps to reduce agency costs, because poorly run companies have lower stock prices and more easily become takeover targets. Conversely, in concentrated ownership systems such a market does not exist, so that private benefits of control obtained by controlling shareholders are subject to few constraints. Accordingly, concentrated owhership firms tend to be managed in a different fashion than widely dispersed ones. The former often act to maximize the private benefits of control for their controlling shareholders, whereas the latter seek to increase the market price of their stock. ${ }^{22}$

\section{B) Causes and consequences of different ownership models}

The exact reasons behind the wide gap between ownership structures in concentrated and dispersed systems are still debatable. Scholars have struggled to find explanations for the persistence of ownership concentration in countries throughout the world. The justifications range from the fragility of the protection granted to minority shareholders to the social norms surrounding the financial markets.

According to most scholars, the combination of weak minority protection ${ }^{23}$ and high private benefits of control ${ }^{24}$ provides the best formula to explain the existence of concentrated ownership. Indeed, both factors are significantly conrelated, since private benefits of control describe precisely the situation in which controller shareholders can obtain benefits for themselves to the detriment of the minority.

Lucian Bebchuk and Mark Roe argue that high private benefits of control deter the transition to a dispersed ownership model since majority shareholders will not be compensated by existing shareholders for relinquishing the great benefits arising from control, they will be reluctant to give up their control when raising extra capital. ${ }^{25}$

La Porta et al., recognizing the role played by minority shareholder protection, argue that these legal rules may be endogenous. Countries with economically and politically powerful controlling shareholders may feel compelled to enact laws that entrench such shareholders and reduce minority rights. ${ }^{26}$ Another way to address this issue, they argue, is to classify legal

\footnotetext{
22 John C. Coffee, Jr., Racing Towards the Top?: The Impact of Cross-Listings and Stock Market Competition on International Corporate Governance, 102 CoLUM. L. REv. 1757, 1764 (2002).

${ }^{23}$ La Porta et al., supra note 11, at 505. La Porta et al. point out that empirical studies demonstrate that countries with strong minority protection present the highest level of share ownership dispersion. $1 d$.

${ }^{24}$ John C. Coates IV, Ownership, Takeovers and EU Law: How Contestable Should EU Corporations Be? (Harvard Law School Discussion Paper no 450) 12 at www.law.harvard.edu/programs/ olin_center/ (last visited Apr. 2, 2004).

${ }_{25}$ Lucian Arye Bebchuk \& Mark J. Roe, A Theory of Path Dependence in Corporate Ownership and Governance, 52 STAN. L. REv. 127, 137 (1999).

${ }^{26}$ Arnoldo Wald observes that the drafters of the 1976 statute consciously increased the allowed proportion of açỏes preferenciais and ações ordinárias in order to facilitate financing of Brazilian corporations while making it possibie for Brazilian entrepreneurs to keep control of the companies. See Amoldo Wald, A Obrigação de Fazer Oferta Pública e a Transferência de Controle no Direito Brasileiro, 302 Revista Forense 49, 49 (1988).
} 
systems by the origin of their commercial law rather than by their actual legal rules. Under this view common law affords better protection to minority shareholders (and consequently generates greater ownership dispersion) than does civil law. ${ }^{27}$ This could be a reasonable explanation for the differences between Brazilian and U.S. corporate systems.

In response to La Porta et al.'s conclusions about the superior performance of the common law with respect to the civil law in furthering liquid markets and dispersed ownership, John Coffee argues that "correlation does not prove causation" and that "[n]orms do matter, but exactly when and to what extent remain more problematic issues". 28 These assumptions are justified by the fact that the differences in countries' corporate laws do not explain satisfactorily the variations in the private benefits of control across countries and the influence of social forces independent of any legal sanction to constrain managers and controlling shareholders. ${ }^{29}$

Furthermore, it is important to recognize that the effect of minority protection on the emergence of dispersed ownership might have been overstated. Indeed, as Coffee points out, "legal developments have tended to follow, rather than precede, economic change." 30 Other scholars have cited political reasons to explain ownership concentration. They claim that social democracies stymie dispersed ownership. The reason given for such a statement is that the government's influence on managers-in the sense of emphasizing distributional considerations and favoring employees over capital owners-significantly increases agency costs in the public firm, thus thwarting the transition to the dispersed ownership model..$^{31}$ Alternatively, much. evidence also indicates that ownership concentration works as an instrument for powerful families and governments to reinforce each other and control economies in the Third World. ${ }^{32}$

In sum, the differences in ownership structures are not the result of one single factor, but of a multitude of causes. It is likely that all the previously identified factors play a part in shaping the country's corporate organization. The identification of the factors involved, however, is of the utmost importance, especially when policymakers have expressly adopted the goal to further ownership dispersion, as in Brazil. ${ }^{33}$

\section{C) Ownership concentration in Brazil}

Although we should not distegard some characteristic features of Brazilian economic history, we can to a large extent attribute ownership concentration in Brazil to the factors discussed in the previous section.

\footnotetext{
${ }^{27}$ La Porta et at., supra note 11 , at 505.

${ }^{26}$ Coffee, supra note 20 , at 2175-6.

$28 / d$.

${ }^{30}$ Coffee, supra note 8 , at 7 .

31 See Mark J. Roe, Political Preconditions to Separating Ownership from Corporate Control, 53 Stan. L. ReV, 539, 543 (2000).

${ }^{32}$ Coffee, supra note 18 , at 79.

33 John W. Anderson, Jr., Corporate Governance in Brazil: Recent Improvements and New Challenges, 9 L. \& Bus. Rev. Am, 201, 204 (2003).
} 
First, it is worth noting that the expression "ownership concentration" is used in the sense of describing the presence of a controlling shareholder. Indeed, the extensive adoption of dual-class shares by Brazilian corporations has led to a peculiar situation, in which stable majority control is combined with widely dispersed nonvoting stock. ${ }^{34}$

Article 15 of the Lei $6.404 / 76$ (the Brazilian corporations statute) provides that corporations can have two species of stock: açōes ordinárias (also known as $\mathrm{ON}$ ), which grant voting rights, and açôes preferenciais (usually called PN), which, though usually nonvoting, confer in return financial advantages to their holders. Until 2001, PN stock could be issued at a ratio up to two-thirds of the company's total stock. The recent alterations to Lei $6.404 / 76$ brought into effect by Lei 10.303 reduced the allowance of PN stock issuance to $50 \%$ of the company's total stock, with the purpose of reducing the controller's entrenchment with the ownership of a low percentage of the firm's stock, made available by the dual-stock mechanism. ${ }^{35}$ The provision, however, only applies to companies incorporated after the enactment of the statute, so that its effects will be noticeable only in the long run.

Brazilian economic history can also explain how the concentrated ownership structure emerged. The ownership concentration is due to a large extent to governmental action in the twentieth century. In the 1930 s and 1940s, the Brazilian government took charge of funding corporations, especially through public financial institutions. Subsequently, Brazil's corporatesector development became linked to the industrialization process, which took place in connection with high tariff protections against imports and cheap financing for the corporations. Following the 1970s, Brazil faced a massive debt crisis. This scenario, also characterized by a de-leveraging of the corporate sector, reinforced the ownership concentration in Brazilian companies, caused in part by the lack of competition in such an unfriendly economic setting. ${ }^{36}$

The privatization process carried out in the 1990 s generated certain changes in the usual capital concentration structure of Brazilian corporations, since local business groups had to build partnerships with foreign corporations and financial institutions in order to participate in the relevant bidding procedures; this process initiated a more representative shared-control experience in Brazilian corporations. On the other hand, foreign firms acquired control of a considerable number of privatized companies so that the shared control initiatives arising from this process did not undermine the ownership structure of Brazilian corporations. ${ }^{37}$

Furthermore, the weakness of the protection afforded to minority shareholders in the Brazilian legal system is well-known. Inadequate minority protection is one of the main causes for the recent decrease in trading volume on the São Paulo Stock Exchange (Bovespa),

\footnotetext{
${ }^{34}$ Ricardo Ferreira de Macedo, Limites de Efetividade do Direito Societário na Repressão ao Uso Disfuncional do Poder de Controle nas Sociedades Anônimas, 118 ReVISTA DE DIREmTo MERCANtIL 167, $177(2000)$.

${ }^{35}$ However, while security exchanges advocate that atl shares should have voting rights, Brazilian corporations insist on the necessity of PN in a country where dynamic entrepreneurs are scarce and where competent elites need to find an instrument in between common stock and debentures. In this respect see Wald, supra note 5 , at 4 .

${ }^{36}$ Anderson, supra note 33 , at 206.

${ }^{37} / d$. at 207.
} 
from $\$ 1$ billion in 1997 to $\$ 150$ million in $2001 .{ }^{35}$ The 30 to 1 ratio-represented by foreign direct investments of $\$ 30$ billion per year (in the form of partnerships or joint ventures) and primary equity issuances of roughly $\$ 1$ billion per year during the 1990 s-ptovides further evidence. These figures indicate that the fragility of corporate governance in Brazil might lead foreign investors to invest in the country directly, but not as minority shareholders. ${ }^{39}$

In addition, private benefits of control in Brazil reach extremely high levels. One method used to quantify these benefits compares the difference of the share price in the sale of a controlling block with its price after the announcement of the block trade. The eleven Brazilian transactions revealed an average premium of around $65 \%$, while in the United States and Canada this figure is only $2 \% .{ }^{40}$

In effect, vote value in Brazil is between a quarter and a third of the total value of the country. The average controller-shareholder in Brazil can have as little as a sixth of the total cash-flow rights and still be able to extract up to $37.5 \%$ of the cotporation's total value. Therefore, an increment of $21 \%$ over the ownership of $16.5 \%$ cash flow rights is expropriated out of the company value. Conversely, common-law countries show private benefits lower than $10 \%{ }^{41}$

\section{PART II - OWNERSHIP STRUCTURES AND TAKEOVER REGULATION}

Given that takeover rules differ significantly in Brazil and in the United States, this study aims to identify the reasons for such divergent legal treatment. In Brazil, the whole discussion focuses on the requirement of a mandatory bid to the minority shareholders to sell their shares in each transaction involving the sale of control. This rule is regarded as a fundamental mechanism for the protection of minority shareholders. In the United States, however, the primary concern for takeover regulation involves the leeway conferred to the board of directors to ward off hostile takeover attempts.

\section{A) Mandatory public bids in Brazil}

There are no statutory provisions or case law in Brazil regulating takeover defenses in hostile takeover attempts. The core of Brazil's legal tegulation of transfers of control concerns the regime of the so-called "mandatory public offering." In its original form, the mandatory public offering rule, also referred as the "mandatory bid" rule or "tag-along" rights, imposes on the acquirer of a target company the obligation to offer minority shareholders the opportunity to sell their shares at the same price offered to the controllers.

Although the mandatory public offering is a traditional feature of Brazilian corporate law, its regime has not been stable over time. Indeed, it has suffered significant changes due to political pressures arising out of the domestic economic situation.

${ }^{36}$ Coffee, supra note 22 , at 1776 .

39 ld. at 1775 .

40 Erik Berglöf \& Mike Burkart, European Takeover Regulation, 18 Econ. Pot'r. 171, 192 (2003).

41 Tatiana Nenova, The Value of Corporate Votes and Control Benefits: A Cross-Country Analysis (Harvard University, Sept. 21, 2000) 38, at http:/papers.ssrn.com/sol3/papers.cfm?cfid= $221634 \&$ cftoken $=7463198 \& a b s t r a c t$ id $=237809$ (last visited Apr. 2, 2004 ). 
First introduced to the legal system by Lei $6.404 / 76$ (the corporations statute, enacted in 1976), the mandatory public offering provision conferred on minority shareholders the right to sell their shares at the same price offered to controlling shareholders in a transaction for the transfet of control. In the 1990s, however, due to the government's wave of privatizations, important provisions of corporate law were modified, including the mandatory bid requirement. Since the state was the controller-shareholder of public corporations, the mandatory-bid rule was eliminated in order to enable the government to keep the all the premium obtained by the sale of the companies to private acquirers.

By doing away with the public offering requirement, the so-called "Lei Kandir" in 1997 (Lei 9.457) allowed the occurrence of a series of oppressive measures against the minority shareholders. In most situations, after purchasing control of the company, the new controllers would buy a significant amount of the outstanding shares in the market, thus gradually reducing the liquidity of the remaining stock. After that, controllers would promote the delisting of the company and squeeze out the minority paying them below the market price of their shares. ${ }^{42}$ In a famous case from 1998, a tender offer by J.C Penney to acquire a Brazilian retailer created political furor when it offered no premium at all to shareholders that did not take part in the controlling block. ${ }^{43}$

In response to the claims of corporate scholars and security market specialists, in 2001 the legislature passed Lei 10.303, which modified some articles of Lei 6.404/76, with the explicit purpose of improving minority shareholders' protection in publicly held corporations. "The changes included the reintroduction in Brazilian law of a modified version of the mandatory public offering requirement. Nevertheless, recognizing that controllers should be entitled to a larger slice of the control prenium, the new statute requires the bidder to give minority shareholders the opportunity to sell their shares at no less than $80 \%$ of the price paid to the controller shareholders.

Hence, the new Article 254-A does not reintroduce the principle of equal treatment between controllers and minority shareholders in the transfer of control. On the contrafy, it expressly allows differentiated treatment to actions of the same class, since the açōes ordinatrias that make up the control block are worth more than those held by minority shareholders, ${ }^{44}$ Due to ownership concentration, in Brazilian corporate practice, control transfers usually occur in a direct manner through the transfet of the control block. ${ }^{45}$

\footnotetext{
42 Modesto Carvalmosa, Comentários a Lei de Sociedades anónimas 148 (2003).

${ }^{43}$ The case is cited by Coffee, supra note 22 , at 1808 . This case gave rise to a lawsult whose main issue involved full and fair disclosure requirements. The court held that PN stockholders could not contest the absence of disclosure of the price paid to the controliers, since the protection awarded to minority shareholders in this regard extended only to those that owned ON stock. Tribunal de Justiça do Rio Grande do Sul. Apelação Clvel no 70006446447, Sexta Câmara Civel, Relator Desembargador Carlos Alberto Alvaro de Oliveira, julgado em 15/10/2003.

${ }_{54}$ CaRvalhosa, supra note 42 , at 149.

45 id. at 165 .
} 
Article 254-A applies whenever cash or assets are given in consideration for the transfer of control. In the opinion of the Comissão de Valores Mobiliários (CVM), ${ }^{46}$ the absence of a premium over the market value of the shares does not eliminate the requirement of a mandatory bid. The policy underlying this interpretation is that control has intrinsic economic value, even if the sale occurs at a price equal to or below the market price of the shares. There is a presumption that it is in the minority shareholders' best interest to sell their shares at the moment of the control transfer, because of the risk of decrease in the shares' liquidity following the company's acquisition. ${ }^{47}$

The new statute resolved the uncertainty regarding the scope of the mandatory bid by establishing that only the holders of açōes ordinárias have the right to the bid. Before that, there was a significant controversy over the issue. ${ }^{48}$ There were arguments for the opinion that the mandatory bid should also be extended to shareholders that own PN stock, i.e., that entitle the stock's owner to greater participation on the dividends but that grant no voting rights. Greater authority, however, already recognized that only stockholders of $\mathrm{ON}$ were entitled to the privilege of the bid. ${ }^{49}$

\section{B) U.S. takeover law}

The central question in the American cases, explored most fully in Delaware, is the extent to which a court will confer discretionary power on the corporation's directors, within the limits of the business judgment rule, to defend against an actual or prospective hostile offer. ${ }^{50}$

Many of the legal discussions derive from two different views on corporations. The "property" conception of the corporation argues that the corporation exists to maximize the wealth of its shareholders. For the property school the markets are generally efficient, and better results are obtained if buyers and sellers are free to transfet corporate control. The "entity" scholars, by contrast, consider the corporation as an institution whose purpose is broader than merely increasing stockholder profits. They argue that the interests of all constituencies

${ }^{46} \mathrm{CVM}$ is the Brazilian agency in charge of the regulation of the securities market, performing the equivalent function of the U.S. Securities and Exchange Commission (SEC).

${ }^{47}$ CARVAlhosa, supra note Error! Bookmark not defined., at 184.

${ }^{48}$ Scholars justify the exclusion of PN stockholders from the scope of the mandatory bid by arguing that only equal shares shouid receive equal treatment by the time of the control transfer. Since PN stockholders do not play a political role in the company, they should not be entitled to share the control premium. See Wald, supra note 26 , at 49 .

${ }^{49}$ See, for instance, this important decision of Superior Tribunal de Justiça, the court in charge of harmonizing the interpretation of Brazilian federal legislation, holding that "only minority shareholders that hold açōes ordinárias are protected by the corporate statute." Superior Tribunal de Justiça. Recurso Especial no 2276/RJ, Primeira Turma, Relator Ministro Geraido Sobral, julgado em $04 / 02 / 1991$.

${ }^{50}$ Deborah de Mott, Comparative Dimensions of Takeover Regulation, in KNIGHTS, RADERS \& TARGETS: The impact of the Hostile Takeover 398, 406 (John C. Coffee, Jr et al. ed., 1988). 
should be taken into account, and that the board of directors should play this role and be allowed to "just say no" to hostile bids. ${ }^{\text {sl }}$

In Unocal Corporation v. Mesa Petroleum Co, the Delaware Supreme Court held that the decision of the board to prompt a tender offer by a corporation for its own shares in response to a hostile tender offer should be measured by the standard of the business-judgment rule, since the board acted in good faith and after reasonable investigation, and the measure was reasonable in relation to the threat posed. ${ }^{52}$

In Revlon, Inc. v. MacAndrews \& Forbes Holdings, the Delaware Supreme Court decided that once the sale of control becomes inevitable, the board's responsibilities under the Unocal standards changed. As the board can no longer protect corporate policy and effectiveness, the whole objective of defensive measures becones moot. Therefore, the Court held that the duty of the board should switch from the preservation of the company as an entity to auctioning the best price for the stockholders. ${ }^{53}$

In contrast, in Paramount Conmunications, Inc. v. Time Incorporated, the Delaware Supreme Court refused to extend Revlon's application to situations that could be construed as putting the corporation up "for sale." The Court then decided that the contested Time-Warner merger agreement did not trigger Revlon duties, and that the business judgment rule protected the board's decision to preserve Time's "culture" by choosing to merge with Warner. ${ }^{54}$

In Paramount Communications Inc. v. QVCNetwork Inc, the same court tried to distinguish Revlon and Time-Warner. According to the Court's opinion, in the latter case neither corporation could be said to be acquiring the other, so that control of both remained in a large, fluid, and changing market. ${ }^{55}$ The Court then held that, when a majority of a corporation's voting stock is acquired by a single person or by a cohesive group, there is a sale of control, so that the main duty of the target's board of directors is to obtain the best value reasonably available to its stockholders. ${ }^{56}$

Most scholarly work on the topic focuses on explaining and harmonizing a series of apparently inconsistent Delaware Supreme Court decisions. "Can the board just say no?", "What triggers Revlon?", and "What constitutes a change of control?" are among the main issues in the takeover debate.

The attempt to find consistency in Delaware takeover jurisprudence has led to different sorts of rationalizations. Efforts range from the construction of a "control-based" model of takeover law, which claims that the separate spheres of board-of-director and shareholder control offer a framework to understand Delaware Supreme Court decisions, ${ }^{57}$ to

\footnotetext{
${ }^{51}$ William T. Allen et al., The Great Takeover Debate: A Meditation on Bridging the Conceptual Divide, 69 U. CHI. L. REV. 1067, 1075-6 (2002).

s2 Unocal Corporation v. Mesa Petroleum Co., 493 A.2d 946, 958 (1985).

${ }^{53}$ Revlon, Inc. v. MacAndrews \& Forbes Holdings, 506 A.2d 173, 182 (1986).

54 Paramount Communications, Inc. v. Time Incorporated, 571 A.2d 1140, 1150-1 (1990).

${ }_{55}$ Paramount Communications Inc. v. QVC Network, inc., 637 A.2d 34, 47 (1994).

$56 / d$, at 51 .

57 Troy A. Paredes, The Firm and the Nature of Control: Toward a Theory of Takeover Law, 29 J. CoRP. L. 103, 106 (2003).
} 
a "corporate policy" model, which argues that management can choose whatever informed corporate policy it believes in good fath to be in the interest of the company and of its shareholders, except when the policy triggers Revlon duties. ${ }^{58}$ Nonetheless, there is also authority for the view that Delaware cases involving takeover defenses are essentially inconsistent, ${ }^{59}$

\section{C) The effect of ownership structure on takeovers}

As discussed above, the main concerns of Brazilian and U.S. takeover regimes differ significantly. In this section, I consider how the pattern of ownership concentration or dispersion affects the likelihood of hostile takeover attempts and, consequently, the focus of the given legal system's takeover regulation.

Due to the evident separation of ownership and control in most U.S. companies, corporate governance performance in the United States has to deal with agency costs arising from such a scheme. Henry Manne in 1965 introduced the expression "market for corporate control," arguing that the decrease in management quality would lead to the fall of the market price of a company's shares, thus creating the appropriate environment for a takeover attempt. 60 Takeovers, then, would be an efficient mechanism for recovering ill-managed corporations ${ }^{61}$ and would serve to mitigate the structural agency costs. ${ }^{62}$

Takeovers have long been regarded as a means of replacing incompetent managers with more efficient ones. Companies with poor recent performance and low stock prices are more likely to become takeover targets. Therefore, the abstract threat of a takeover attempt and the fear of losing their positions constitute important incentives for managers to improve the company's value in order to raise share prices.

In John Coffee's words, "In market-centered economies, the market for corporate control is the ultimate disciplinary mechanism, and the hostile takeover, its final guillotine. In contrast, in concentrated ownership systems of corpotate governance, the takeover has historically played only a minor role. But, once again, that pattern is changing rapidly." 63

As mentioned, hostile takeovers are not a universal phenomenon. On the contrary, their very existence is due to a corporate system in which shares are widely held. ${ }^{64}$ In fact,

\footnotetext{
${ }^{58}$ Richard E. Kihlstrom, \& Michael L. Wachter, Corporate Policy and the Coherence of Delaware Takeover Law, 152 U. PA. L. Rev. 523, 572 (2003).

59 HAMILTON \& MACEY, supra note 7, at 1228.

${ }^{60}$ Henry G. Manne, Mergers and the Market for Corporate Control, 73 J. OF POL. Econ. 110.

${ }_{61}$ William J. Carney \& Mark Heimendinger, Appraising the Nonexistent: The Delaware Court's Struggle with Control Premiums, 152 U. PA. L. ReV, 845, 861 (2003).

62. Arnoud W.A. Boot \& Jonathan R. Macey, Monitoring Corporate Performance: The Role of Objectivity, Proximity, and Adaptability in Corporate Governance, 89 CORNELL L. ReV. 356, 381-2 (2004). ${ }^{63}$ Coffee, supra note 18 , at 20.

54 Notice, however, that the one of the most celebrated benefits of takeovers-the corrective effect on the agency costs stemming from the separation of ownership and controlm-does not exist in concentrated ownership systems. Despite the detrimental impact of private benefits of control to the minority, it is possible to posit that the incentives are better aligned between managers anct shareholders to increase corporate performance, as management ultimately is in the hands of identified controllers.
} 
takeovers and concentrated ownerships are substitute mechanisms of corporate control because lower ownership concentration makes stock markets more liquid and thus facilitates takeovers. ${ }^{65}$ Where high levels of ownership concentration exist, hostile attempts are also impractical and transfers of control usually take place only through voluntary transactions. In Brazil, as in Continental Europe until recently, takeovers are very rare. ${ }^{66}$

Takeovers face both technical and structural barriers. Technical barriers typically refer to those impediments to takeovers that result from rules allocating power between various participants in the corporation, i.e., taking away from shareholders the decision whether or not to sell their shares, and permitting the board to establish defenses. Structural barriers, on the other hand, arise from economic phenomena such as ownership concentration. ${ }^{6 ?}$

Technical barriers are represented by the so-called "shark repellants" found in the United States, and they operate to fustrate takeover attempts when they would be otherwise attractive. Structural barricrs, conversely, make it unlikely that hostile takeover bids will emerge, because the ownership concentration makes it unfeasible to gain control over a company without entering into a voluntary transaction with current controllers.

As Allan Ferrel indicates, "[T]akeover rules governing the use of defensive tactics by target management, along with many other so-called 'technical barriers,' are critically important when there is a wide dispersion of ownership and control rights. If a company has a controller, whether that control is due to a large ownership stake or disproportionate voting rights, then these rules rapidly fade in importance. An acquisition will only occur when-and only when-the controller has somewhat lost control." ${ }^{68}$ Deborah Mott points out, furthermore, that the feasibility of hostile bids in any country depends in large part on the pattern of share ownership of that country, on shareholders' ability to transfer their shares freely, and on the voting rights allocated to publicly-held shares. ${ }^{\text {it } 69}$

The evident conclusion is that a hostile bid will not be made for a company unless there are enough shares available for sale (typically the public shares) to provide sufficient voting rights to give a new owner control over the company.

One possibility available in all systems of corporate law is having separate classes of stock that hold different voting rights. ${ }^{20}$ Dual-class (re)capitalization works as an efficient barrier to hostile-takeover attempts by consolidating the control of the company in the hands of insiders. ${ }^{71}$ Dual-class structure, adopted by Brazilian corporations in order to combine

\footnotetext{
${ }^{6} 5$ La Porta et al., supra note 11 , at 509.

${ }^{6}$ De Mott, supra note 50 , at 401.

${ }^{87}$ Allen Ferrell, Why Continental European Takeover Law Matters (Harvard Law School Discussion Paper no 454) 1 п.2 at www.law.harvard.edu/programs/olin_center/ (last visited Apr. 2, 2004)

${ }^{68} \mathrm{id}$. at 1.

${ }^{69}$ De Mott, supra note 50 , at 400 .

$70 /$ d. at 402 .

${ }^{71}$ Greg A. Jarrel \& Annette B. Poutsen, Dual Class Recapitalizations as Antitakeover Mechanisms: The Recent Evidence, $20 \mathrm{~J}$. FIN. ECoN. 129, 149 (1988).
} 
financing of the corporation in the public market and entrenchment of majority shareholders, ends up being one of the most effective takeover defenses, ${ }^{72}$

In Brazil, as used to be the case in Continental Europe (and still is, though to a lesser extent $)^{33}$, acquisitions occur through negotiation between the acquirer and the target company's management, and transactions take place outside the public exchanges. As a result, takeovers tend to be friendly and the main issue concerns the protection of minority shareholders in this transaction. Indeed, the protection of minority shareholders has been a major concern in Brazil, since the underdevelopment of the country's financial market is attributed to the biased regulation to the benefit of controllers. ${ }^{24}$

The United States, on the other hand, is renowned for its vast minority protection and for its thriving financial markets, at least when compared to other countries in the world; minority protection is thus not so much of an issue in this regard. Ownership structure by itself renders hostile takeovers rather attractive. Therefore, the conflict between the rights of shareholders to sell their shares and the power of the board of directors to establish goals for the company becomes the central concem.

The existence of extensive regulation on hostile takeovers can be explained through wide share dispersion considerations. Yet the exact nature of U.S. takeover law requires further explanation. ${ }^{75}$ Management control in the United States shapes the character of takeover law, since managers are the ones who choose whether and where to reincorporate. Therefore, Delaware takeover law tends to be as manager-friendly as possible without, however, making takeovers so unlikely that the company's value decreases. ${ }^{76}$

\section{ISSUE}

\section{PARTII - CONTROL PREMIUM: DIFFERENT RESPONSES TOTHE SAME}

In Part II we observed that the focus of Brazilian and U.S. legal systems with regard to takeover regulation differs significantly and that this gap is due to the difference in the countries' ownership structures. For instance, the noted absence of legal rules on takeover

\footnotetext{
72 The dual-class structure is such an efficient takeover defense that the 2001 draft of the European Directive on takeovers, in order to enhance control contestability, intended to adopt the so-called "break-through" rule to vold this mechanism once a hostile attempt was announced. This rule was later dropped from the draft, but the concept remains. See Berglof \& Burkart, supra note 40, at 174 . ${ }^{73}$ The old pattern in Europe is being replaced. From 1985 to 1999 , the percentage of takeovers involving at least one European party rose from $15 \%$ to $43 \%$. Coffee, supra note 18 , at 20 .

${ }^{74}$ See Part $)(C)$.

75 Like the United States, England has a widely dispersed ownership structure. While hostile takeovers are extensively regulated, English law in this aspect differs significantly from U.S. law. Under the self-regulatory City Code on Take-Overs and Mergers, board defenses are discouraged, and an obligation is imposed on the control buyer to buy out the remaining minority shareholders at the same price it paid to the control seller. Coffee, supra note i 8 , at 1 n.23.

"76 Gutan Subramanian. The Influence of Antitakeover Statutes on Incorporation Choice: Evidence on the "Race" Debate and Antitakeover Overreaching, 150 U. PA. L. ReV. 1795, 1863 (2002). This study shows that companies usually migrate to jurisdictions with anti-takeover statutes, but not to the ones with severe anti-takeover statutes, as Massachusetts, Ohio, and Pennsyivania. Id. at 1873.
} 
defenses in Brazil stems from the lack of hostile tender offers.

This part of the analysis refers to an issue common to both systems: entitlement to control premiums. Unlike hostile takeover, whose possible existence depends on the country's ownership structure, sale of control transactions and the consequent controversy about entitlement of control premiums exist both in the United States and in Brazil. Here, too, the approach varies, but since the factual situation may be roughly the same in both systems, some arguments can transfer more easily from one system to another. Yet also in this regard, the different rules adopted by both countries and their desirability can be justified by each country's ownership structure and closely related problems.

A) Control-premium sharing requirements in the United States and in Brazil

Scholars have given various explanations for the empirical observance of control premiums in the sale of control transactions. Control premiums are defined as the empirical difference that exists between the price a buyer is willing to pay for shares that convey the control of the corporation and for shares that do not grant control. A number of general economic and legal factors cause control premiums to emerge. Sources of control premiums include synergy value, expropriation value, and pure control value. Synergy value arises whenever two assets tum out to be more valuable when combined than they are in isolation; expropriation value refers to the ability to expropriate wealth through minority shareholders; and pure control value is the residual value arising from management. ${ }^{77}$

Some scholars argue that takeover premiums prove that takeovers are "value-creating." Control premiums have also been explained by a downward-sloping demand curve, which justify the premium as a mechanism to induce more optimistic shareholders to sell their stock. ${ }^{78}$ Other scholars claim conversely that the gains obtained by target shareholders tesult simply from bidder overpayment. ${ }^{79}$

In the United States, the rules regarding control premiums have fluctuated over time. In the famous case of Perlman v. Feldman, ${ }^{80}$ the court imposed on the controlling shareholders the obligation of sharing with the minority the premium obtained by selling the controlling block of shares. According to Robert Hamilton, Perlman v. Feldmann reflects a trend in the 1960s in the direction of requiring controllers to share control premiums with the minority. The rule, however, was adopted only to be rejected in later cases. "The long-settled law," which allows controllers to keep the premium, has after been affirmed in an impressive number of cases. Thus, a general rule has prevailed that controlling shareholders may obtain a premium for their shares, and they need not share such premium with other sharcholders. ${ }^{8}$

\footnotetext{
${ }^{77}$ John C. Coates IV, "Fair value" as an Avoidable Rule of Corporate Law: Minority Discounts in Conflict Transactions, 147 U. PA. L. REv. 1251, 1274 (2004).

${ }^{78}$ Lynn A. Stout, Are Takeover Premiums Really Premiums? Markel Price, Fair Value, and Corporate Law, 99 Yale L. J. 1235, 1264-6 (1990).

79 See Bernard S. Black, Bidder Overpayment in Takeovers, 41 STAN. L. Rev. 597, 629 (1989).

${ }^{80}$ Perlman v. Feldmann, 219 F.2d 173 (1955).

${ }^{81}$ Robert W. Hamilton, Private Sale of Control Transactions: Where We Stand Today, 36 CASE W. REs. L. REV. 248, 249 (1985).
} 
For instance, in Zetlin v. Hanson Holdings, Inc, a minority shareholder argued that all shareholders should be entitled to an opportunity to share equally in a premium paid for control of a corporation. The New York Court of Appeals held that except in cases of looting, conversion of a corporate opportunity, fraud, or bad faith, a controller shateholder is entitled to keep the premium obtained by the sale of the controlling block. ${ }^{82}$

The court further argued that awarding the minority shareholders an opportunity to share equally in any premium paid for a controlling interest would require a radical change in the manner in which controlling stock interest is transferred, and that such a change would best be done by the legislature. Indeed, the court pointed out that the shate requirement would call for sale-of-control transactions to take place only through an offer to all shareholders, i.e., through a tender offer. ${ }^{83}$ What the court did, therefore, was to reject imposing a mandatory public offering requirement in order to fulfill a transaction involving the sale of controlling interest.

Today, the controller shareholder is not generally required to share with the minority shareholders the control premium received by selling his control block. The standard rationale for this view is that minority shareholders will assess these aspects when assessing the price to pay for a minority interest in the corporation's stock. ${ }^{84}$

Under U.S. law, sharing of control-premium concerns also matter in a different scenario: a hostile takeover that may shift control from public shareholders to a controller. In Paramount Communications, Inc. v. QVC, the Delaware Supreme Court characterized the control premium as the price paid not only in exchange for the value of a control block of shares, but also as compensation to the minority shateholders for their resulting loss of voting power: The Court considered that there was a loss of voting power, since before the acquisition the public shareholders (in the aggregate) owned a majority of Paramount's voting stock. Control of the corporation was not vested in a single person or group, but in the lluid aggregation of unaffiliated stockholders. Where a majority stockholder exists, however, minority stockholder votes become mere formalities. ${ }^{85}$

The court further observed that once control has shifted, current shareholders will have no opportunity in the future to sell their shares at a control premium. Hence, the loss of another opportunity for minority shareholders to obtain a control premium triggered the

\footnotetext{
62 Zetlin v. Hanson Holdings, Inc., 397 N.E.2d 387, 388 (1979).

is 1 d. at 389.

${ }^{84}$ Carney \& Heimendinger, supra note 61, at 870 . Nevertheless, as the authors point out, the Delaware Supreme Court has embraced the idea of awarding control premilus to minority shareholders under the appraisal statute. The use of control premiums to determine the value of shares in appraisal circumstances was first fully developed in Rapid-American Corp. v. Harris. Yet the author also highlights that control premiums only exist before a transaction on the transfer of control. Delaware's current approach toward control premiums, however, has been significantly criticized, as it also confers control premiums to minority sharehoiders when the actual probability of a takeover attempt is quite remote, and, on the other hand, may not allow sharing of control premiums when control transfers actually take place.
}

${ }_{85}$ Paramount Communications, Inc. v. QVC, 637 A.2d 34, 43 (1994). 
obligation of the board of directors to "take the maximum advantage of the current opportunity to realize for the stockholders the best value reasonably available." $\$ 6$

Therefore, conceming hostile takeovers, the duty of the board varies according to the kind of acquisition. The result is different when the transaction is structured as a stock-forstock deal and the bidder has no controlling shareholder, because the target shareholders can have another opportunity to enjoy a future control premium for the combined company. ${ }^{87}$

In Brazil since 2001, minority shareholders have the right to sell their shares when control is transferred, through the mandatory tender-offer requirement, but are no longer entitled to an equal share of the control premium. Since the passage of Lei 10.303/01, the mandatory-bid rule has to give all holders of ações ordinárias the right to sell their shares at a price no less than $80 \%$ of the one paid to the controllers. Through this new regime, the major concern seems to be not the equal allocation of the control premium, but the right to shareholders to exit the corporation in fair conditions when control is to be alienated.

B) Policy arguments in favor of and against the different rules

Thete are two dominant schools of academic thought conceming the rights of minority shareholders to share premiums when controllers sell their shares (or the mandatorybid rule). ${ }^{85}$ According to the equal-sharing school, minority shareholders should always have the right to share the control premitm obtained in a sale of control. On the other hand, the deregulatory school believes that control premiums should not have to be shared. The current doctrine, however, does not align with any of the academic schools, as it allows controlling shareholders to keep the entire premium for themselves in most, but not all, transactions. ${ }^{89}$

William D. Andrews, in his famous article in favor of the sharing of control premiums, argues that "[a] controlling shareholder should not be free to sell, at least to an outsider, except pursuant to a purchase offer made equally available to other shareholders; or, put in the affimative, that one of the rights of the minority shareholders is to have an equal opportunity with all other stockholders to participate ratably in any sale of shares pursuant to a favorable offer for the purchase of controlling shares in their corporation." 90

\footnotetext{
8a 1 d. at 44.

${ }^{87}$ Paredes, supra note 57 , at 103.

${ }^{88}$ In this part, the arguments for and against sharing the control premium and the mandatory-bid rule will be used interchangeably, since the connections between the arguments in this regard outweigh the distinctions of the concepts. The concepts, however, are far from being identical. There can be a mandatory-bid rule without a full control-premium sharing requirement, which is found in Article 254-A of Lei $6.404 / 76$, and a control-premium sharing requirement without a mandatory-bid rule, which occurs when the entitlement of the minority to control premiums is recognized ex post, as U.S. courts rule in looting cases. However, as the Zetlin court noted, the enforcement of a general requirement to share the control premium requires the implementation of a mandatory tender offer each time control is to be sold. Zetin, 397 N.E.2d at 389.

${ }^{89}$ Einer Elhauge, The Triggering Function of Sale of Control Doctrine, $59 \mathrm{U}$. CHI. L. Rev. 1465, 1465 (1992).

${ }^{90}$ William D. Andrews, The Stockholder's Right to Equal Opportunity in the Sale of Shares, 78 HARV. L. REV. 505, $506(1965)$.
} 
Scholars have put forth several justifications for the rule for equal treatment. One of the arguments-the main one in Brazil-claims that a transaction for the sale of control brings with it the danger that, after a transfer of controlling shares, corporate affairs may be run in a way that is harmful to the remaining shareholders who did not have an opportunity to sell their stock. The rule of equal opportunity, however, is not dependent upon harm to the corporation. ${ }^{91}$ Other scholars, subsequent to Berle and Means, have viewed control as a corporate asset, thus requiring an equal division of the gains from a transfer of control between controllers and minority shareholders. ${ }^{92}$

Considerations of equality and faimess stemming from the "social-political canon of equal treatment" also augur in favor of the mandatory-bid rule, whose objective is to implement de facto equal treatment of all shareholders in the target company. In Bergström and Högfeldt's words, "[T] he specific legislative objective [of the mandatory-bid rule] is to prevent a raider from taking out the 'widows and orphans' cheaply and paying the 'real price' only to the controlling shareholders." 93

Still, under a law-and-economics perspective, rules requiring the sharing of the control premium cannot be justified in most situations. Imposing equal treatment on noncontrolling shareholders may serve to deter not only unproductive control transfers, but also productive ones. Therefore, applying such a rule tends to lessen the under-deterrence of harmful control transfers, but leads to over-deterrence of efficient ones. ${ }^{94}$ Moreover, economists start from the premise that, as any other voluntary transaction, there is a strong presumption that the transfer of corporate control promotes a reallocation of resources to where they are more highly valued. ${ }^{95}$

Since the mandatory-bid rule decreases the occurrence of both desirable and undesirable transactions, we must examine the likelihood that the new controller, rather than increasing firm value, will extract private benefits of control at the expense of minority shareholders. ${ }^{96}$ Additionally, given that the mandatory-bid rule reduces the probability of a takeover, there is a drawback when this rule is applied to firms with concentrated ownership, since such application might reduce sales of control blocks and thereby "lock in" the current controller, even if another controller would be able to add value. ${ }^{97}$

It is important to note that the interaction between the advantages and drawbacks of a control-premium sharing requirement vary according to the corporate governance characteristics of the country. Economists contend that the mandatory-bid rule might trigger results contrary to its express goal. In general, the rule turns out to be detrimental to target

\footnotetext{
$91 / d$ at $517-8$.

92 Frank H. Easterbrook \& Daniel R. Fischel, Corporate Control Transactions, 91 YALE L.J. 698, 716 (1982).

${ }_{93}$ Clas Bergström \& Peter Högfeldt, The Equal Bid Principle: An Analysis of the Thirteenth Council Takeover Directive of the European Union, 24 (3) \& (4) J. BUS. FIN. AND AccT, 375, 377 (1997).

94 Elhauge, supra note 89 , at 1466 .

95 Easterbrook \& Fischel, supra note 92 , at 705.

96 Ferrell, supra note 67 , at 6 .

${ }^{97}$ /d. at 8 .
} 
shareholders, since efficient transactions will be hindered. Therefore, in a mature market such as the U.S. market, the absence of the rule seems justifiable. In the words of Anupam Chander, 'The law generally permits the controlling shareholder to sell her shares at a'control premium.' In doing so, the law recognizes and validates the extra value of control. But it does so on behalf of the minority". ${ }^{98}$

Nevertheless, in countries where private benefits of control are high-such as Brazil, as we have seen-the mandatory-bid rule might play an important part in protecting shareholders in a takeover situation. ${ }^{99}$

\section{CONCLUSION}

We can explain the hierarchy of the main issues of takeover law in the United States and in Brazil by looking at each country's ownership structure. When widely dispersed stock creates an environment conducive to hostile takeover attempts, courts and legislatures create laws to deal with the issue. In Brazil, where the likelihood of a hostile takeover is drastically low, regulation of takeover defenses has not yet emerged.

We can attribute the regimes regarding the division of the control premium in the United States and in Brazil to the different levels of both countries' corporate-law and financialmarket development. Since the weak protection of minority shareholders is considered to stymie Brazil's financial market development, sharing of the control premium is justified as an instrument to avoid the perpetration of further abuses.

In the United States, however, where general minority-shareholder protection is adequate and securities markets well developed, the legal system is in better conditions to comply with the law-and-economics statement that the absence of a sharing requirement triggers a more efficient allocations of resources.

Brazilian policymakers should begin to familiarize themselves with the takeover issues arising in the United States, since stock dispersion-which facilitates hostile takeovers-is one of main goals of Brazil's recently created Novo Mercado. ${ }^{100}$ Brazil's Novo Mercado consists of new listing options conceived by Bovespa (the São Paulo Stock Exchange) in order to react to the legislature's apathy in passing investor-friendly regulations. ${ }^{101}$ Until 2001 , despite the constant demands of investors and corporate scholars, the legislature did not take a position about increasing minority protection in Brazilian financial market. Since adherence to the Novo Mercado (and consequently to higher standards of transparency and efficiency in corporate governance than even those in the amended Lei 6.404) is voluntary, this approach has the advantage of being less politically confrontational. ${ }^{102}$

\footnotetext{
98 Anupam Chander, Minorities, Shareholder and Otherwise, 113 YALE L. J. 119, 131 (2003).

as Ferrell, supra note 67 , at 6 .

${ }^{100}$ Anderson, supra note 33, at 204.

101 Coffee, supra note 22 , at 1806 .

102 Peter A. Gourevitch, The Politics of Corporate Governance Regulation, 112 Yale L. J. 1829, 1875 (2003).
} 
Furthemore, Novo Mercado goes beyond the statute on a variety of topics, including the statutory requirement of a mandatory-bid rule. It requires the granting of "tag along" rights to all non-controlling shareholders so that, in a sale-of-control transaction, they have the right to sell their shares at the same price paid to the controller. Additionally, Novo Mercado prohibits the issuance of nonvoting shares and imposes compliance with a "one-share, one-vote" rule. These rules address the deficiencies of Lei $6.404 / 76$ with regard to both the $80 \%$ minimum requirement to be paid to non-controlling shareholders according to the mandatory-bid rule, and to the $50 / 50$ allowance for the issuance of nonvoting stock. Novo Metcado thus demonstrates that Brazil is taking importantsteps to improve corporate-governance mechanisms that lead to better minority protection and, consequently, create an atmosphere more favorable for the emergence of a dispersed ownership structure.

All these recent developments provide excellent reasons for why the issues of hostile takeovers faced by policymakers in the United States should start to interest Brazilian policymakers. As Allen Ferrell points out, despite its ownership concentration and the low probability of takeovers, "timing" makes a difference, ${ }^{104}$ Best takeover regulation is enacted when there is not a significant number of potential targets, since at that moment political pressures from apprehensive managers and labor organizations are reduced. Indeed, scholars suggest that state competition in the United States-combined with the fact that the decision of whether and where to reincorporate rests in the hands of managers-has led to expressive incorporation in states with anti-takeover statutes, which is detrimental to shareholders' interests. ${ }^{105}$

Moreover, U.S. academic works provide interesting insights for a better understanding of Brazilian takeover law. Although under Brazil's current corporate-governance setting the mandatory public offering rule seems justifiable (and the limitation to $80 \%$ of the price paid to controllers seems subject to criticism), the comparative-law perspective suggests that the advantages of the rule are neither apparent nor universal. Whereas the rule at present avoids major expropriations of minority shareholders, further developments in Brazil's corporategovernance structure may point in the direction of another kind of regulation in order to take full advantage of the benefits of a market for corporate control.

103 Coffee, supra note 22 , at. 1806

104 Ferrell, supra note 67 , at 13 n.2.

${ }^{105}$ Lucian Bebchuk et al., Does the Evidence Favors State Competition in Corporate Law?, 90 CAl. L. REV. 1775, 1821 (2002). 